\title{
PATIKÁK HARCA A VEVŐKÉRT
}

\author{
Hortolányi Árpád László - Domán Szilvia - Mucha László
}

\section{Összefoglalás}

A kutatásunk célja annak feltárása, hogy Gyöngyös város és vonzáskörzetében milyen okok, milyen preferenciák alapján választanak az emberek gyógyszertárat. Ugyanaz a fogyasztó más és más élethelyzetekben, vajon ugyanazt a patikát választja-e, a hüség kialakitható-e ezen a speciális piacon.

Primer kutatásaink elsö etapjaként megvizsgáltuk a szolgáltató oldalát, abból a célból, hogy jelenleg mit tesznek meg, illetve milyen további eszközöket alkalmazhatnának a fogyasztók megszerzése és megtartása érdekében. A kvalitativ kutatás alkalmával egyéni mélyinterjúk készültek az eladói oldalon jelenlévö gyógyszertárvezetökkel és gyógyszerészekkel.

A kutatás lefolytatásában segitséget nyújtott helyismeretünk, hiszen helyi lakosokként a Gyöngyös városában üzemelö - különbözö méretü és elhelyezkedésü - gyógyszertárakban vásárlás során elvégzett megfigyelések eredményeit is felhasználhattuk.

A megkérdezés során fóbb célkitüzéseink között szerepelt a hálózati tagság elönyeinek, hátrányainak, a gyógyszertárvezetök piacismeretének feltárása, valamint a promóciók hatásának megitélése a kinálati oldal szereplöinek szemszögéböl.

Kulcsszavak: gyógyszerpiac, patikaláncok, fogyasztói magatartás, kvalitativ kutatás, mélyinterjú

\section{JEL: M31}




\title{
FIGHT OF PHARMACIES FOR CUSTOMERS
}

\begin{abstract}
The aim of our research is to find out on what basis people choose a pharmacy in the city of Gyöngyös and its agglomeration. Whether the same consumer chooses the same pharmacy in different life situations and whether loyalty can be developed in this special market.

As a first step in our primary research, we looked at the supplier's side to see what they are doing to gain and retain consumers at the moment and what additional tools they could use. During the qualitative research individual in-depth interviews were conducted with pharmacy managers and pharmacists.

Our familiarity with the area proved helpful in conducting the research, as we could also use the results of the surveys conducted in pharmacies operating in different sizes and locations in Gyöngyös as local residents.

The main objectives of the survey were to explore the advantages and disadvantages of operating in networks, the market knowledge of the pharmacy managers, and to evaluate the impact of promotions from the point of view of the actors on the supply side.
\end{abstract}

Keywords: pharmaceutical market, pharmacies, consumer behaviour, qualitative research, in-depth interviews

\section{JEL: M31}




\section{Bevezetés}

Témaválasztásunk aktualitását az indokolja, hogy napjainkra a gyógyszervásárlási szokások a korábbi évtizedekhez képest jelentős változáson mentek át. A patikák tehát nincsenek könnyü helyzetben, egyre élesebb a verseny a vevők megszerzése és megtartása érdekében. (Nádor, 2014)

A gyógyszerek értékesítése során alkalmazott marketing és promóciós tevékenység átszövi a vásárlók hétköznapjait (Buzási, 2014). Emellett a kisvárosban, ahol élünk, jelenleg tíz közforgalmú gyógyszertár üzemel, igen eltérő feltételekkel, nyitva tartással, a város különböző pontjain, úgy a belvárosban, mint a peremterületen egyaránt. Egy nem egészen harmincezer fós lakosságú városban ez igen nagy szám, mely a vásárlók számára ugyan kedvező, az egyes patikák helyzetét azonban nem könnyíti meg. Úgy véljük, komoly erőfeszítéseket kell tenniük a vevők megszerzéséért és megtartásáért.

Korábbi, a témával kapcsolatos kutatások eredményei azt mutatták, hogy a gyógyszertár fekvése, azaz a lakóhelyhez mért távolsága a leginkább befolyásoló tényező a patikaválasztásban, ezt követi a kiszolgálás színvonala, azaz a patikus barátságos hozzáállása, valamint fontos a széles termékválaszték is a helyszíneken. Emellett a megfelelő szolgáltatásban részesített vevők többsége jellemzően hűséges marad gyógyszertárához, legközelebb is ugyanoda tér vissza vásárolni (Sz.n, 2009).

Jelen kutatásunkban arra a kérdésre keressük a választ, hogy a kínálati oldal szereplői hogyan látják a saját helyzetüket, lehetőségeiket ebben a helyzetben.

\section{Helyzetelemzés}

Napjainkban a gyógyszertárakra úgy kell tekinteni, mint minden más átlagos kereskedelmi egységre. Kemény marketing munkát kell folytatniuk a fogyasztók kegyeiért (Birchall, 2018). Ehhez meg kell érteni, a vásárló motivációit, hiszen ha belegondolunk minden patikában elérhető általában ugyanaz az árukínálat, a vásárló mégis preferálni fogja valamelyik egységet. Többnyire nem találomra megyünk be az üzletekbe, így a gyógyszertárakat is valamilyen szempont szerint osztályozzuk magunkban és annak megfelelően cselekszünk, amikor választunk.

Ugyanakkor a piacnak ez a szegmense sokkal jobban szabályozott, mint a kereskedelem egyéb területei (Jogtár, 2016). A piacra történő belépés a jogi szabályozások miatt igen nehéz. Nemzeti szinten igen kevés szereplőről beszélhetünk, akiknek a marketing tevékenysége korlátok közé van szorítva. A piacot szinte oligopol piacként lehetne jellemezni müködése alapján, de az árakat ugyanakkor mégis egyfajta szabad verseny jellemzi (Szalkai, 2004). A fogyasztó elérését célzó marketing-mix eleme- 
inek megválasztásához a patikáknak is meg kell határozni a saját célcsoportjukat, mely nem is olyan egyszerü, mint azt először gondolnánk. A betegségben szenvedő és a kozmetikumokat vásárolni szándékozó emberek motivációja között jelentős különbség van, mégis mindkettő elérendő fogyasztóként határozható meg. És ne feledkezzünk meg azokról sem, akik valamilyen hirtelen hatásnak a következtében a pillanatnyi csábításnak engedve vásárolnak különböző termékeket, hiszen akár ez is előfordulhat a mai gyógyszertárak kínálatát tekintve. A Hungaropharma Zrt.(2018) 2017. évi éves jelentése alapján ez a piac igen jentős, mintegy 800 milliárd forintot tett ki az adott évben. A gyógyszertárakban forgalmazott, vényköteles készítményekhez az ellátás biztonság fenntartása és a hozzáférhetőség biztosítása érdekében az állam jelentős támogatást nyújt, amit az 1. ábra szemléltet (NEAK, 2018).

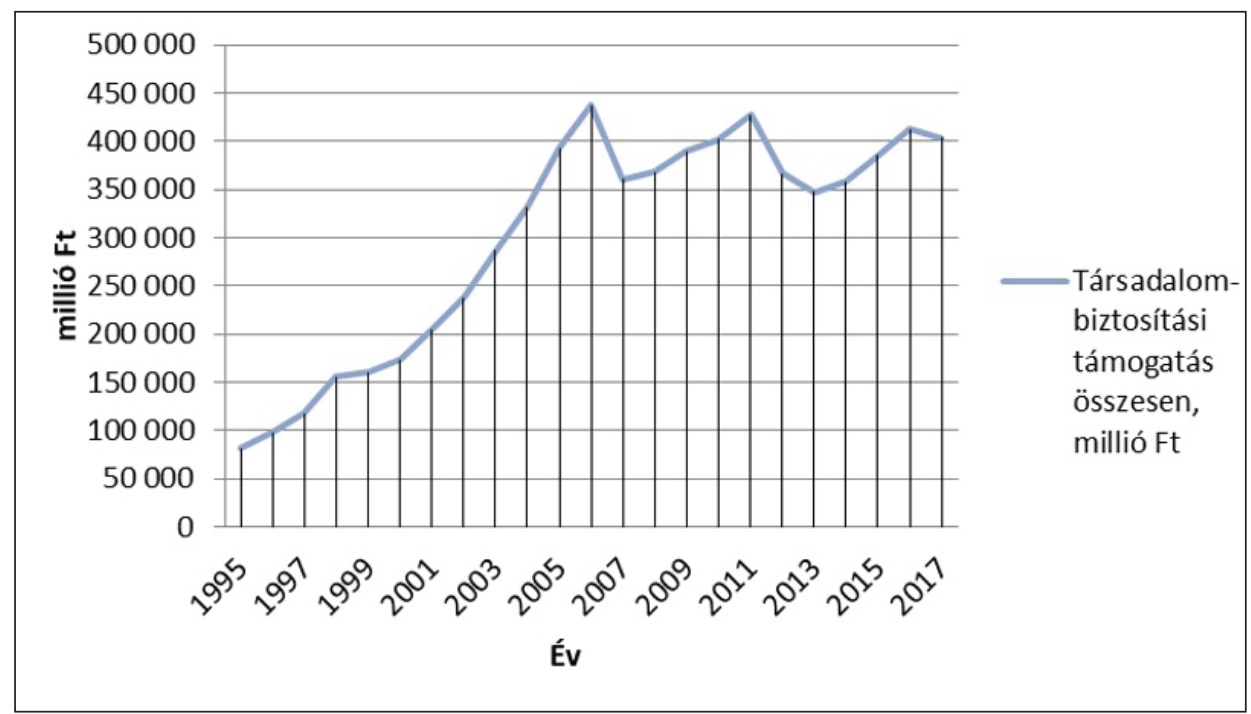

\section{1. ábra Gyógyszerek és gyógyászati segédeszközök társadalombiztosítási támogatása összesen 1995-2017 között (millió Ft)}

Forrás: Nemzeti Egészségbiztositási Alapkezelö (2018), Statisztikai Evkö̈nyv 2017. alapján, saját szerkesztés

A 2014. évi magyarországi gyógyszerfogyasztási adatokat összehasonlítva az EU átlaggal megállapítható, hogy a receptre kiadható gyógyszerek fogyasztásának aránya megfelel az EU átlagnak (49\%). A többi tagország esetében ez az érték 40-60\% között mozgott. Ugyanakkor a vény nélkül értékesíthető gyógyszerek és gyógyhatású készítmények fogyasztása 12\%-al meghaladta az EU-s (35\%) átlagot. Ahogy a 2. ábrán látható, hazai régiónkénti bontásban vizsgálva az adatokat, nem mutatható ki jelentős eltérést a vényköteles készítmények fogyasztásában. A nyolc régió tekinteté- 
ben nagyjából 48-52\% között mozog ez az érték. A recept nélkül értékesíthető készítmények fogyasztása jól követi a vényre kiadható gyógyszerek használatát mindössze 3-6 százalékponttal marad alatta, mely alól a Nyugat-Dunántúli régió marad csak el. Ebben a régióban 15\%-al alacsonyabb a fogyasztási szint a vény nélkül kiadható gyógyszerek tekintetében (KSH 2018). Az adatok alapján elmondható, hogy a hazai gyógyszerpiac hasonló eredményeket produkál, mint az Európai Uniós átlag, míg a vény nélkül forgalmazható készítmények esetében túl is szárnyalja azt. Fontos adatok ezek, mivel egyrészt megmutatják, hogy a szektor hazai gazdasági mutatói nem térnek el a nemzetközi trendektől, másodsorban rávilágítanak arra, hogy a szabadáras készítmények - melyek a patikák profitjához szignifikánsan járulnak hozzá - kiemelkedően jól értékesíthetők hazánkban.

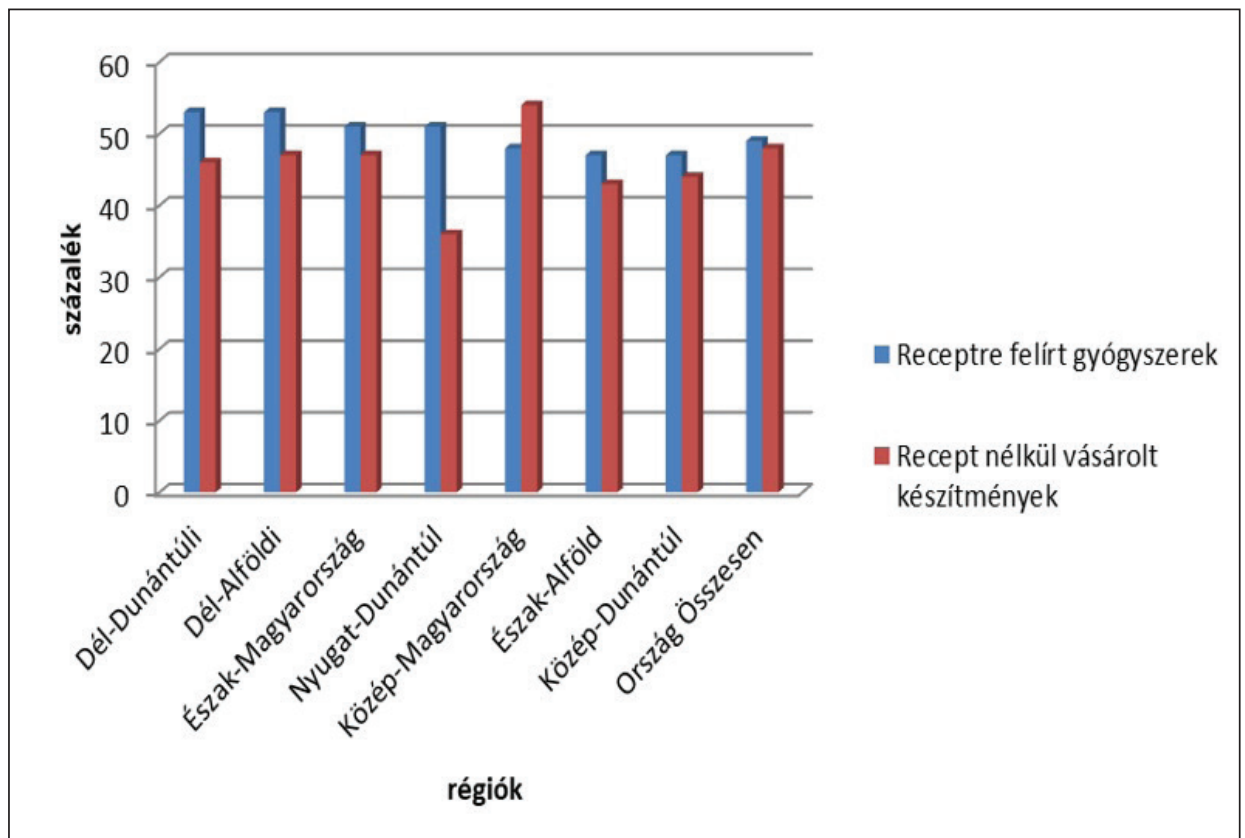

2. ábra Gyógyszerszedők aránya az adatfelvételt megelőző két hétben régiók szerint, 2014 (százalék)

Forrás: KSH, A 2014-ben végrehajtott európai lakossági egészségfelmérés eredményei, összefoglaló adatok (2018) alapján, saját szerkesztés

Társadalmunk öregszik, mely nagymértékben befolyásolja a gyógyszeripart. Egyre több embernek és egyre nagyobb mennyiségben van szüksége gyógyszerekre. A növekedési mozgatórugók közé tartozik a népesség elöregedése és a megnövekedett egészségtudatosság. (Sz.n. 2019) A jövedelmi viszonyok ugyanakkor jelentősen de- 
terminálják a hozzáférést. A korosodó társadalom azt is jelenti, hogy egyre több ember kerül inaktív állapotba, mely társadalmi rétegnek az egyre csökkenő aktív rétegtől befolyó állami bevételekből kell biztosítani az ellátását. Belátható, hogy ez csak az állami bevételek növelésével, illetve az ellátásra fordított összegek relatíve, vagy tényleges csökkentésével oldható meg. A gyógyszerfogyasztás mind a vényre kiadható, mind a vény nélkül vásárolható készítmények esetében a nőket jellemzi magasabb százalékban. Ez a különbség azonban az idősödéssel csökken és 65 éves kor felett szinte kiegyenlítődik a nemek között (KSH 2018). (3. ábra)

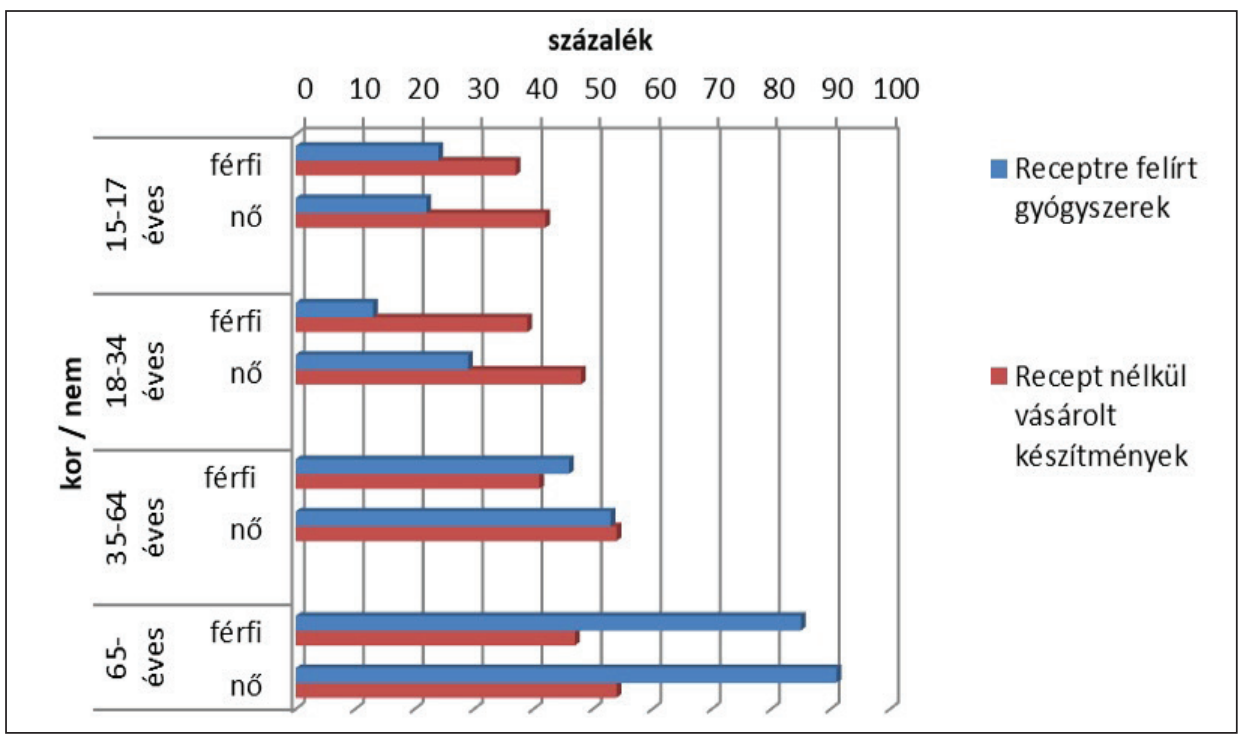

3. ábra Gyógyszerszedők aránya az adatfelvételt megelőző kéthétben nem és korcsoport szerint, 2014 (százalék)

Forrás: KSH, A 2014-ben végrehajtott európai lakossági egészségfelmérés eredményei, összefoglaló adatok (2018) alapján, saját szerkesztés

A Hálózatban Működő Gyógyszertárak Szövetsége (HGYSZ 2018) megbízásából a Szinapszis Piackutató és Tanácsadó Intézet országos, reprezentatív felmérést készített a gyógyszerészek körében 2018. augusztus - október folyamán. A kutatás során megkérdezett gyógyszerészek a fenntarthatósági korlátot a támogatott gyógyszereken érvényesíthető alacsony árrésben, a magas működési költségekben és a szakemberhiányban látják. (4. ábra) Az alacsony árrés problémája egy olyan külső szabályozó eredménye melyre nincs ráhatásuk. Ugyanakkor optimizmusra adhat okot, hogy Uniós átlagban, hazánkban kiemelkedő a szabadáras termékek értékesítése, mely kompenzálhatja az állam által alacsonyan tartott árréssel forgalmazott gyógyszereken jelentkező bevételkiesést. (5. ábra) 


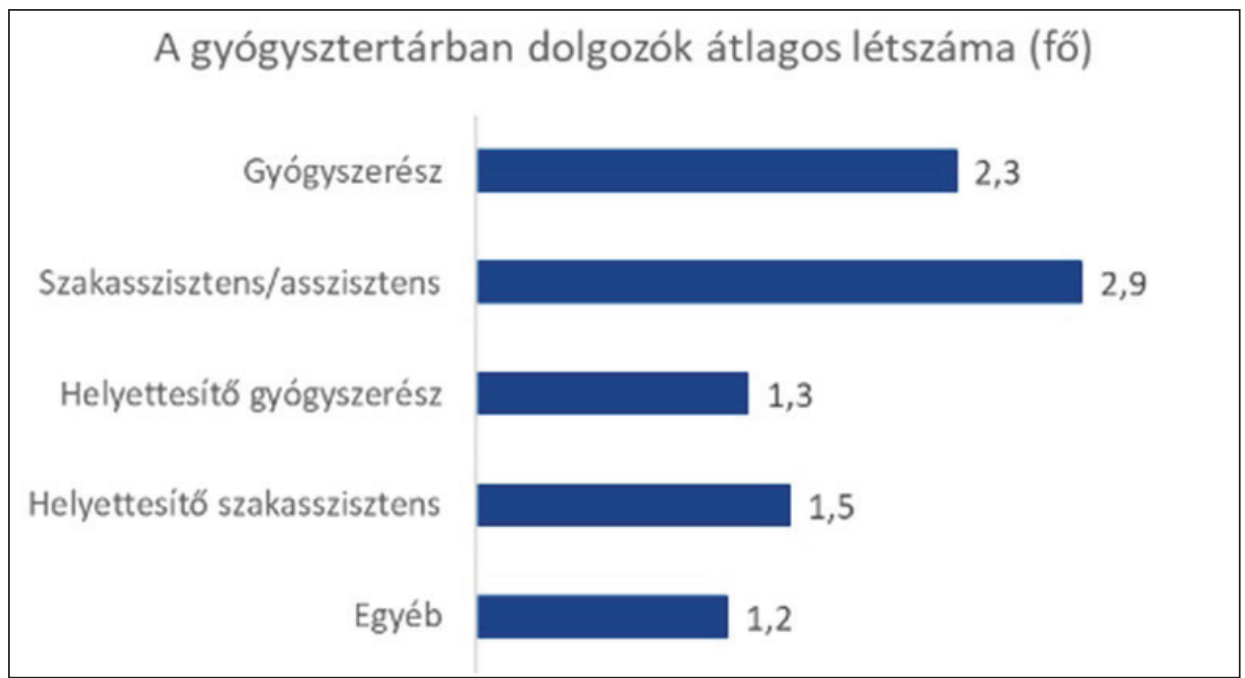

\section{4. ábra A Gyógyszertárban dolgozók átlagos létszáma (fö)}

Forrás: HGYSZ (2018) A gyógyszerészek véleményét kérdeztük

https://hgysz.hu/blog/a-gyogyszereszek-velemenye-a-gyogyszertarbanforgalmazhato-termekekroll

\section{A gyógyszertárban forgalmazott termékek aránya}

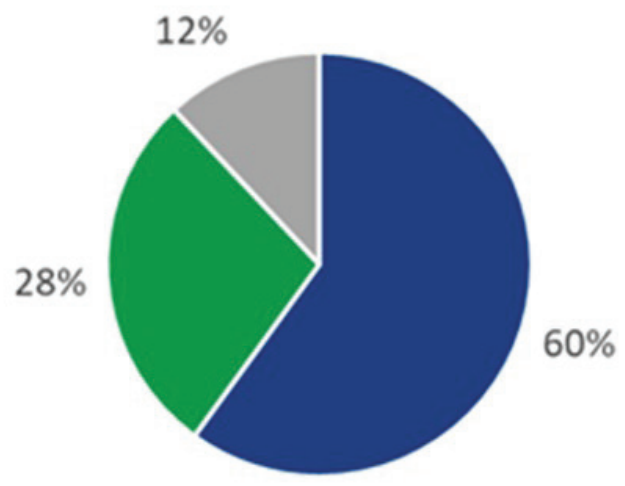

- Vényköteles gyógyszerek = OTC gyógyszerek = Egyéb termékek

5. ábra A gyógyszertárban forgalmazott termékek aránya (százalék)

Forrás: HGYSZ (2018) A gyógyszerészek véleményét kérdeztük

https://hgysz.hu/blog/a-gyogyszereszek-velemenye-a-

gyogyszertarbanforgalmazhato-termekekroll 
Mint minden más szektorban, az egészségügyben és így a gyógyszerészetben is kiemelkedő szakemberhiány mutatkozik hazánkban. (6. ábra) A patikák versenyt futnak a szakemberekért, melyet csak jelentős költséggel nyerhetnek meg, hiszen folyamatosan emelni szükséges a béreket a megtartó hatás kiváltása érdekében. Ez a béremelés annál meredekebb minél nagyobb a szakemberhiány az egyes régiókban.

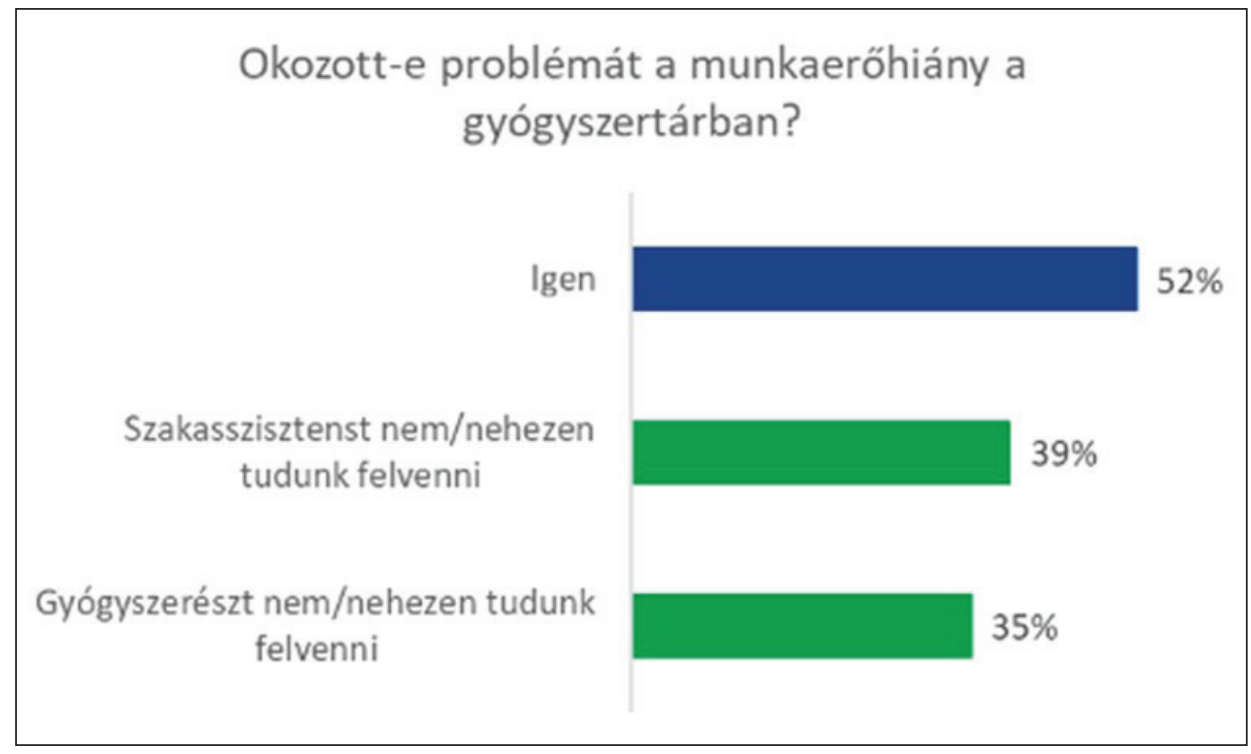

6. ábra A szektor dolgozói milyen arányban érzékelik a munkaerő hiányát (százalék)

Forrás: HGYSZ (2018) A gyógyszerészek véleményét kérdeztük

https://hgysz.hu/blog/a-gyogyszereszek-velemenye-a-

gyogyszertarbanforgalmazhato-termekekroll

A kiskereskedelemben - melyhez nagymértékben hasonlít a közforgalmú gyógyszertárak müködése - azt tapasztaljuk, hogy a gazdaság régiós helyzete, a kereskedelmi egység városi vagy rurális elhelyezkedése igen nagy jelentőséggel bír, a forgalom és a profit növelése szempontjából. Ebből a nézőpontból is eltérő pályát futnak be a patikák. Csepeti-Bauer (2018) megállapítja, hogy a telephelyi adottságok nem bírnak jelentőséggel, mindegy, hogy hol van a patika, egyedül a gyógyszertár előtti átmenő forgalom van hatással az árbevételre. A városok sokszínűsége, vonzó tulajdonsága jelentős hatást nem fejt ki a patikák forgalmára. A jól megválasztott stratégia, a vezető stratégiai szemléletmódja, ugyanakkor egy kevésbé vonzó helyen lévő gyógyszertár müködését is eredményessé teheti. 


\section{Anyag és módszer}

A gyógyszer-kiskereskedelem eladói oldalának vizsgálata érdekében kvalitatív kutatást láttunk szükségesnek, mely a gyógyszertárvezetők körében lefolytatott egyéni mélyinterjúk formájában valósult meg. Vizsgálatunk fókuszában az állt, hogy miben látják az egyes gyógyszertárak vezetői saját patikájuk erősségét, gyengeségét, véleményük szerint mik a vásárlók főbb preferenciái a Gyöngyösön található számos gyógyszertár választása esetében.

\section{A mélyinterjú módszere}

Az egyéni mélyinterjúk esetében a megkérdezettek köre általában nem nagyszámú (Lehota, 2001.34.p, 40. p.).Elsőként a téma gondolati vázát határoztuk meg. Mivel az interjú viszonylag kötetlen, ezért a válaszok összehasonlítása nem egyszerü.

A mélyinterjú párbeszéd a kérdező és a válaszadó között, egy kb. 50-90 percet felölelő kötetlen beszélgetés (Domán et al, 2009). Ezt a marketingkutatási módszert gyakran használják szakértői megkérdezések esetében, ahol a megkérdezett egyéni meglátásainak, véleményének feltárása a cél (Bércziné, 1999). A módszer alkalmas lehet arra, hogy felszínre kerüljenek az interjúalany motívumai, árnyalt véleménye, melyek kvantitatív módszerekkel nem, vagy csak korlátozottan tárhatók fel. Az eredmények feldolgozása sem statisztikai módszerek alapján történik, az alacsony minta-elemszám miatt a kapott eredmények nem általánosíthatók. (Malhotra, 2009) Ugyanakkor a mélyinterjúk kitűnően alkalmazhatók a későbbi kutatások céljainak, hipotéziseinek, a standard kérdőív megalapozására meghatározására (Veres-Hoffmann-Kozák 2006). A mélyinterjú egy rugalmas módszer, mely a témák széles skálájának vizsgálatát teszi lehetővé. Szükséges hozzá egy, a fó- és melléktémák felsorolását tartalmazó interjúvázlat, így megfogalmaztunk olyan kérdéseket, melyekre feltétlenül választ szerettünk volna kapni (Lehota, 2001). Az interjú lebonyolítása a válaszadó megszokott, természetes közegben történt, így az interjúalanyok magatartása vélhetöen a természeteshez leginkább hasonló volt, a válaszokat nem manipulálta a megfelelni akarás, vagy a szokatlan környezet (Veres-Hoffmann-Kozák 2006).

\section{Vizsgálandó cél}

A mélyinterjú készítésével célunk volt, átfogó képet kapni a Gyöngyös városában működő gyógyszertárak vezetőinek véleményéről, tapasztalatairól a patikák helyzetével és a vásárlók főbb preferenciáival kapcsolatban. 
Konkrét célkitűzéseink a következők voltak:

- Hálózati tagság előnyei, hátrányai

- Vásárlói szokások ismerete

- Vásárlói szegmensek

- Promóciók hatása a vásárlókra

- Saját gyógyszertár helyzetének megítélése

- Versenytársak ismerete, megítélése

\section{Hipotézisek a mélyinterjúval kapcsolatban}

A mélyinterjú elkészítésekor az alábbi hipotéziseket vettük alapul:

- A gyógyszertárak számára a hálózati tagság jellemzően előnyös. (Koncsek, 2018)

- A vásárlói szokások alakításában nagy szerepe van a gyógyszerész személyének.

- A gyógyszerészek is felismerték a marketing jelentőségét az értékesítésben. (Sz.n, 2018)

- A gyógyszertár forgalmát jelentősen befolyásolja a településen belüli elhelyezkedése.

- Fontos a minél hosszabb nyitvatartási idő.

\section{A minta}

A Gyöngyös városban üzemelő tíz gyógyszertár közül négy vezetőjével készítettünk mélyinterjút. Az interjú alanyok eltérő jellemzőkkel rendelkező egységeket vezetnek. A jelleg a családi gyógyszertártól a nagy hálózathoz tartozó gyógyszertárig terjedt. Célunk a mélyinterjúk alapján nem csupán a fentebb felsorolt céloknak megfelelően információkat szerezni, hanem összehasonlítást is tenni, melyben az eltérő hátterü gyógyszertárak működésének, elfogadásának és népszerűségének azonosságait és a különbségeit is kiemeljük.

\section{Az interjú körülményei}

A mélyinterjúk elkészítésére 2019. március 10. és 15. között került sor. A kérdéseket személyes interjú keretében tettük fel a négy gyógyszertárvezetőnek. Minden esetben 
a kérdezett felkeresésével került sor a személyes beszélgetésre, mely lehetőséget adott az interjúalany számára a „hazai” környezet támogató hatásának kihasználására, és a válaszok összeszedett, külső hatásoktól mentes megfogalmazására.

A megkérdezéses eljárásoknál, így a mélyinterjúnál is ügyelni kell a kérdések pszichológiai és logikai sorrendjére, ezért a vizsgálat során arra törekedtünk, hogy az egyszerű kérdésektől haladjunk a bonyolultabbak felé, és az esetleges kényes, vagy nehezen megválaszolható, elgondolkodásra késztető kérdéseket az interjú végén tegyük fel (Bércziné 1999).

\section{A mélyinterjú eredményei}

\section{Hálózati tagság elönyei, hátrányai}

A megkérdezett gyógyszerészek közül a hálózatban üzemelő egységek vezetői egyértelműen előnyként jelenítették meg a hálózati tagságot. A működési formából kifolyólag több előnyt éreznek, mint hátrányt. A likviditási problémák nem jelentkeznek, minden készítmény beszerezhető és készleten tartható, mely a profit mellett az ellátásbiztonság megteremtésében is jelentős szerepet játszik. A központosított és ezáltal nagy egyedi mennyiségekben lebonyolított beszerzések, segítséget nyújtanak a nem vényköteles termékek árainak alacsonyan tartásában. Az alkupozíció kedvező hatásából adódóan az árrés magasabban tartható, mely profitnövelésre ad lehetőséget. A kedvező beszerzési árak miatt az árrés szűkítésével alacsonyabb kiskereskedelmi árak mellet is hasonló profit érhető el, mint a hagyományos módon üzemelő patikákban. További előny a „valahova tartozás” érzése. Az országos hálózatok az egységes képpel, azonos marketingstratégiával egymásnak is megteremtik a presztízst. A gyógyszertárvezetők válláról leveszik a terhet a központi marketingstratégia alkalmazásával, mivel nem kell kísérletezni azzal, hogy mi lenne a megfelelö, mivel lehetne nagyobb profitot elérni, hanem készen kapják a megoldásokat.

Ugyanakkor a hagyományos módon működő, úgynevezett családi patikákban a szabadságot élik meg előnyként. Nincs kötöttség, nincs elszámolási kényszer, nem kell megfelelni mások által támasztott követelményeknek. Nincs magas marketing költség, nincsenek kötelezően alkalmazandó design elemek. Megemlítették, a személyes kapcsolatok jelentőségét, mivel a vevők nagy része visszatérő, úgymond törzsvásárló. A gyógyszerész az adott fogyasztó jellemzőit és problémáit jól ismerve, személyre szabott megoldásokat tud felkínálni.

A hálózatban üzemelő gyógyszertáraknál hátrányként jelentkezik a volumenek nagysága és a rendelések kötöttsége. A központi beszerzések miatt egyszerre nagyobb mennyiségű gyógyszer érkezik be, melynek a megfelelő raktározása és időben történő értékesítése nagy terhet ró a gyógyszertárvezetőkre. A magas marketingköltségek és 
a központi marketing előirásoknak való megfelelés is negatívan érinti a hálózatos gyógyszertárakat.

A családi gyógyszertárak a szerényebb pénzügyi lehetőségeket élik meg hátrányként. Nem tőkeerősek így rendeléseiket csak kisebb tételekben tudják bonyolítani. Ebből egyenesen következik, hogy az alkupozíciójuk sem olyan jó, mint egy patikalánc központi beszerzőjének. Többnyire a fenntartási költségeik tervezését is szűkebb keretek között végezhetik.

Nagy hátrányként éli meg, mindkét típusú üzemeltetési formában mủködő patika a szakképzett munkaerő hiányát, azonban más és más okokat feltételezve. Míg a patikalánc a feszített munkatempó, sokszor a hosszú, esetenként hétvégi nyitva tartás miatt talál nehezen szakképzett alkalmazottat, addig a hagyományos gyógyszertárak a mérsékelt anyagi lehetőségük és az ebből is eredő bizonytalan jövőképük miatt.

\section{Vásárlói szokások ismerete}

A mélyinterjúkban elmondottakat összegezve a patikavezetők úgy vélik, hogy a saját vásárlói körük szokásait jól ismerik. Készleteiket megközelítőleg a fogyasztói igényeknek megfelelően tudják kialakítani, ezzel biztosítva folyamatos gyógyszerellátás zavartalanságát.

A hálózatban üzemelő gyógyszertárak nagyobb árukészletük és tőkeerejük miatt könnyebben tudják kielégíteni a különleges vásárlói igényeket. Ugyanakkor a családi gyógyszertárak a szűkebb, de állandóan visszatérő fogyasztói kör alaposabb ismerete miatt, jobban tudják tervezni a készleteiket.

Míg a nagy forgalmú patikaláncok a tömegek fogyasztói igényeinek teljes körü kielégítésére törekednek, addig a hagyományos patikák inkább egy adott térség lakóinak szükségleteire specializálódnak.

\section{Vásárlói szegmensek}

A gyógyszertárak vásárlói szegmentációt a vényköteles termékek körében nem végeznek, ebben az esetben törvényi előírások alapján ellátási kötelezettségük van. Az OTC termékek körében sem beszélhetünk igazi szegmentálásról, hiszen ezen termékek esetében sem lehet fogyasztói csoportokat képezni ismérvek alapján. A vény nélkül értékesíthető gyógyszerek esetében a gyógyszerésznek az adott szituációban az általa legmegfelelőbbnek tartott készítményt kell ajánlani, szem előtt tartva a gyógyszertár értékesítési céljait. 
Vásárlói szegmensek kialakítására az egyéb készítmények esetében nyílik lehetőség. Ilyenek például a vitaminok és a kozmetikumok. A vitaminok jelentős részét jellemzően a gyermekkel rendelkező vásárlók részére értékesítik, így azok megjelenése, kiszerelése is ennek a szegmensnek megfelelő. A dekor-kozmetikumok között léteznek olyan, csak gyógyszertárban értékesíthető termékek, amik megjelenésükkel és árukkal is magasabb kategóriát sugároznak. Ezeknek a kozmetikumoknak jól elkülönülő vásárlói rétege van. Ugyanakkor a patikák kínálatában megtalálhatóak a pénztárcát kevésbé megterhelő, de megbízható minőségű kozmetikumok is, melyek az átlagos jövedelmi viszonyokkal rendelkezők számára is elérhetőek. A szegmentáció nem speciális jelenség, jól segítheti az egyes fogyasztói csoportok igényeinek feltérképezését. (Baranyi-Bakos-Tóth, 2015)

\section{Promóciók hatása a vásárlókra}

Promóció szempontjából külön kell választani a gyógyszertárak marketing tevékenységét és a gyógyszergyártók marketing tevékenységét. (Birchall, 2018)

A kisebb családi gyógyszertárak költségvetése nem teszi lehetővé a marketingkommunikáció magas szintű alkalmazását. Az ő esetükben az eladáshelyi reklámok alkalmazása képezi a fó promóciós tevékenységet. A marketing munka egy részét leveszi a vállukról a tőkeerős gyógyszergyártók aktivitása.

A gyógyszereiket szakmai fórumokon bemutató, vagy bizonyos termékek esetében reklámozó gyártók, megteremtik a készítmények ismertségét és ezzel forgalmat generálnak a patikának. Az ilyen típusú marketinggel azonban nem lehet az eladási hely iránti hűséget kialakítani, csak a márkahűség növelhető.

A hálózatban üzemelő gyógyszertárak esetében lényegesen nagyobb marketing lehetőségek adódnak. A láncok közös marketingstratégia alkalmazásával megteremtik az azonos arculatot, a széles és mély termékkínálatot, és a versenyképes árakat. Saját akciós újság fogyasztóhoz történő eljuttatásával, honlap üzemeltetésével mindig naprakészen tudják tájékoztatni a vásárlókat az aktuális akciókról, melynek vonzóereje jelentős. Hűségkártya bevezetésével az vásárlások ösztönzése mellett magukhoz kötik a fogyasztót. A hűségkártya alkalmazásával fogyasztói preferenciákat tudnak feltárni, igen széles körben gyüjtve adatokat a láncok kiterjedtsége miatt.

Mindkét formában üzemelő gyógyszertár vezetőinek véleménye abban a vonatkozásban megegyezett, hogy a reklámok hatása mérhető a forgalomban. Ebből is kiemelkedik a televíziós reklámok hatása. Egy televízióban futó OTC készítményről szóló reklám, észrevehetően megemeli az eladásokat az adott termékből. 


\section{Saját gyógyszertár helyzetének megitélése}

A megkérdezett vezetők kedvezően ítélték meg a saját egységeik helyzetét, függetlenül attól, hogy hálózatos, vagy családi gyógyszertárak voltak.

Erősségként a rájuk jellemző speciális tulajdonságokat jelölték meg. Ez a családi patikák esetében a személyes ismeretség, a hagyományok őrzése, a személyre szabott megoldások, a családias hangulat volt. Továbbá szintén egyik előnye ezeknek a patikáknak, hogy többnyire hosszú ideje, több évtizede ugyanott működnek általában ismert, belvárosi területeken. Mindezt hátrányként is megemlítették ugyanis amiatt, hogy általában a belvárosban helyezkednek el, rossz parkolási lehetőségekkel és feltételekkel kell szembesülni a fogyasztóknak.

A hálózatos patikák esetében a vezetők előnyként említették a széles és mély árukészlet, a kedvező árakat, vagy a jó parkolási lehetőséget. Továbbá kiemelt jelentőséggel bír a hosszú valamint állandó hétvégi nyitva tartás, mely jelentős vásárlói létszámot generál ezekben az időszakokban.

Hátrányként egységesen az időnként kialakuló vásárlói sorokat jelölték meg, mely rajtuk kívülálló okokból, a szakdolgozók hiányából adódik.

\section{Versenytársak ismerete, megitélése}

A versenytársait minden gyógyszertárvezető ismeri. Ugyanakkor ez a piac olyan szabályozott és olyan magas belépési korlátok vannak, hogy erős verseny nem alakul ki. Inkább a belső értékesítési elvárások jelentik a kihívást. Mindemellett, ha mégis versenytársat kellene megjelölni mind a családi patikák, mind a hálózatos gyógyszertárak egy másik hálózatban üzemelő gyógyszertárban látnák azt.

\section{Következtetések}

A kvalitatív kutatás eredményeit összefoglalva a következtetéseinket a korábban felállított hipotéziseink alapján vontuk le.

- Megállapítottuk, hogy a hálózati tagság számos lehetőséget nyújt a gyógyszertárak számára. Az arculati és pénzügyi függetlenségük részben megszűnik, ugyanakkor jelentős marketing és anyagi támogatást, biztos hátteret kapnak cserébe. A családi gyógyszertáraknak ezzel szemben ugyan saját arculattal és teljes pénzügyi függetlenség mellett, de szűkösebb anyagi lehetőségek között kell önállóan helytállniuk. Ezek alapján az mondható el, hogy a hálózathoz tartozás több előnnyel jár, mint hátránnyal. 
- A gyógyszerész személye kiemelt az értékesítésben. A személyes eladás jelentősége a tanácsadásban, felvilágosításban, ajánlásban mutatkozik meg, melylyel a gyógyszerész, mint bizalmi személy, nagymértékben tudja befolyásolni a vásárló aktuális és későbbi magatartását. Tehát a vásárlói preferenciák és szokások kialakításában jelentős a gyógyszerész szerepe.

- A marketing szerepe a gyógyszertárvezetők véleménye szerint is jelentős az értékesítésben. A reklámok elérik a célközönséget és észrevehetően megemelik a reklámozott termék forgalmát. A vásárlás ösztönző eszközök alkalmazása mind a vásárlói hüség kialakításában, mind a forgalom növelésében nagy szerepet játszik. Ezekkel a marketingeszközökkel egyre gyakrabban és szélesebb körben élnek a gyógyszerészek.

- A gyógyszertárak településen belüli elhelyezkedése nem befolyásolja számottevően a forgalmukat. Az egyéb külső tényezők köztük kiemelten az officina előtti nagy átmenő forgalom, illetve a jó parkolási lehetőség a közelben viszont jelentős forgalmat generál. Az ezzel kapcsolatban felállított hipotézist az eredmények tehát csak részben támasztják alá.

- A megszokottól eltérő, hosszabb, illetve rendszeres hétvégi nyitva tartás jelentős forgalmat hoz az azt alkalmazó egységeknek. A forgalomnövekedés ezekben a megszokottól eltérő időszakokban gyakran olyan mértékű, hogy az nehezen kezelhető, sok esetben, sorban álláshoz vezet. A nyitvatartási idő meghosszabbítása és kiterjesztése a hétvégékre a fogyasztók kényelmén túl profitnövelési célokat is szolgálhat.

Összegzésként a kvalitatív kutatás során lefolytatott mélyinterjúk lényegében alátámasztották a szolgáltatói oldallal kapcsolatban felállított hipotéziseket, azzal a kiegészítéssel, hogy a gyógyszertár müködésének konkrét helye a településen belül nem bír relevanciával, csak a hely jellegéből (átmenő forgalom, parkolás) adódik forgalomnövekedés.

\section{Hivatkozott források}

[1.] Baranyi A. -Bakos Tóth E. (2015) Typifying Savers by Applying Statistical Methods In: Ferencz, Árpád (szerk.) II. Gazdálkodás és Menedzsment Tudományos Konferencia: Kecskemét, 2015. augusztus 27. : „A vidék él és élni akar” Kecskemét, Magyarország : Kecskeméti Főiskola Kertészeti Főiskolai Kar, (2015) pp. 578-582., 5 p.

[2.] Bércziné Juhos, J. (1999.) Piac- és marketingkutatás a gyakorlatban. CONEX Kft. Budapest, ISBN 9638401230 
[3.] Birchall, G. (2018) Marketing pharmacy as a brand and designing its future. The Pharmaceutical Journal 12 feb 2018, https://www.pharmaceutical-journal.com/careers-and-jobs/careers-and-jobs/career-qa/marketing-pharmacyas-a-brand-and-designing-its-future/20204334.article?firstPass=false (letöltve: 2019.02 .01 .)

[4.] Buzási B. (2012): Látszani a zajban! Reklámeszközök a patikában, Progressive Studio Kft, file://C:/Users/User/Downloads/prg_gyogykomm_20120925_ kreativ.pdf (letöltve: 2019.08.27.)

[5.] Csepeti, Á., Bauer, A.(2018) A Miles-Snow-féle stratégiai tipológia statisztikai tesztelése szabályozott ágazati környezetben. II., STATISZTIKAI SZEMLE, 96 (7). pp. 661-682. ISSN 0039-0690

[6.] Domán, Sz. - Tamus, A. - Totth, G. Marketing alapok - gyakorló feladatokkal. Saldo Kiadó Zrt. 2009. ISBN: 9789636383190

[7.] HGYSZ (2018) Gyógyszerészek véleményét kérdeztük, Hálózatban Működő Gyógyszertárak Szövetsége, https://hgysz.hu/blog/a-gyogyszereszek-velemenye-a-gyogyszertarban-forgalmazhato-termekekrol/ (letöltve: 2019.04.02.)

[8.] Hungaropharma (2018) Éves jelentés 2017., https://www.hungaropharma. hu/Media/Default/Documents/besz\%C3\%A1 mol\%C3\%B3k/2017.\%20 e\%CC\%81vi\%20E\%CC\%81ves\%20jelente\%CC\%81s_Annual\%20Report\%202017..pdf (letöltve: 2019.03.01.)

[9.] Jogtár (2016): Hatályos Jogszabályok Gyüjteménye, 422/2016. (XII. 14.) Korm.rendelet https://net.jogtar.hu/jogszabaly?docid=A1600422.KOR, (letöltve: 2019.02.12.)

[10.] Koncsek, R. (2018) Költséghatékonyság miatt a hálózatokat választja a patikák jelentős része Világgazdaság. https://www.vg.hu/vallalatok/egeszsegugy/koltseghatekonysag-miatt-a-halozatokat-valasztja-a-patikak-jelentos-resze-2-1095865/ (letöltve:2019.03.05.)

[11.] KSH (2018) A 2014-ben végrehajtott Európai lakossági egészségfelmérés eredményei,Összefoglaló adatk., Központi Statisztikai Hivatal 2018. ISBN 978963-235-506-10̈ ISBN 978-963-235-508-5

[12.] Lehota, J. (2001) Marketingkutatás az agrárgazdaságban, Mezőgazda Kiadó, Budapest, ISBN: 9639358258

[13.] Malhotra, N. K.(2009) Marketingkutatás, Akadémiai Kiadó, Budapest,

[14.] Nádor K. (2014) A gyógyszertári szolgáltatási portfólió növelése, mint marketinglehetőség, http://www.aok.pte.hu/docs/gyogyegy/file/NadorKrisztina. pdf (letöltve: 2019.08.31.) 
[15.] NEAK (2018.) Statisztikai évkönyv 2017. Nemzeti Egészségbiztosítási Alapkezelö, http://site.oep.hu/statisztika/2017/html/indexhun.html (letöltve:2019.03.28.)

[16.] Szalkai, Zs. (2004) A gyógyszeripari versenyképesség vizsgálata, különös tekintettel a kórházi piac szerepére. Doktori értekezés. Budapesti Müszaki és Gazdaságtudományi Egyetem

[17.] Sz.n. (2009): Patikaválasztási attitűdök, Szinapszis Kutatás, https://www.szinapszis.hu/hu/hirek/patikavalasztasi-attitdok (letöltve: 2019.03.17.)

[18.] Sz. n. (2018) MARKETING INTO THE PHARMACY, Industry Research, 04.09.2018, https://frog-dog.com/research-marketing-pharmacy/ (letöltve: 2019.02 .15 .)

[19.] Sz. n. (2019) Drug Stores Industry Profile, First Research, 1/21/2019, https://www.firstresearch.com/Industry-Research/Drug-Stores.html (letöltve: 2019.02.15)

[20.] Veres, Z. - Hoffman, M. - Kozák, Á. (2006) Bevezetés a piackutatásba. Akadémiai Kiadó Zrt., Budapest, ISBN: 9789630582926

\section{Szerzők:}

\section{Hortolányi Árpád László}

egyetemi hallgató

EKE GYKRC Kereskedelem és marketing BA

szonart@upcmail.hu

\section{Domán Szilvia}

PhD Főiskolai docens

EKE GYKRC

doman.szilvia@uni-eszterhazy.hu

\section{Mucha László}

PhD-hallgató

Szent István Egyetem Gazdálkodás és Szervezéstudományok Doktori Iskola mucha.laszlo@phd.uni-szie.hu 